UDC: 159.98

DOI: https://doi.org/10.24195/2414-4665-2021-2-3

Fred Voskoboynikov,

BS in Physiology of Human,

MS in Industrial-Organizational Psychology,

Honorary Professor of Psychology

(The Baltic Academy of Education,

35, Dekabristov Str., St-Petersburg, Russia),

129, Idora Avenue, San Francisco, California, USA

\title{
A SYSTEMIC APPROACH TO IMPLEMENTING PSYCHOLOGICAL FACTORS IN MANAGEMENT
}

In this work we will consider some aspects of management as a scientific and applied discipline. Ensuring the effectiveness of management requires a new way of thinking characterized by the systemic, flexible, responsive, and a non-standard approach to the decision making. According to the systemic-structural activity theory, as a scientific basis for self-regulation, human activity is considered to be a goal-directed self-regulative system. The main focus of our discussion will be on what is essential for managerial activity from the psychological perspective. Specific attention will be paid to the way managers relate to subordinates and how this factor effects the group moral and psychological atmosphere in the workplace. Possessing only the technical knowledge in a chosen field of activity does not necessarily make a person effective manager. To achieve the desired objectives and maintain people satisfaction at work place one must be prepared to think of them in human terms. People are filled with thoughts and ideas and they want to experience satisfaction from their implementation. We will present some important factors of the psychological nature which should be applied to the practice of management. Such factors as consideration for subordinates' personality features, their individual style of performance and their communicative anilities, as well as their goals, desires and objectives. The effect of a group environment on individual performance and the phenomenon of psychological compatibility are also considered in this work. We will also briefly dwell on the history of motivation in industry and the emergence of a new direction in managerial activity as a demand of the developing society. At this juncture we will emphasize on how the science of management first emerged in a form of applying a mechanistic approach in managing people's activities in industries and, further, by bringing the human element into consideration in the search for efficiency.

Keywords: management, management styles, activity theory, systemic-structural activity theory, psychological factors in management, personality features, individual style of activity, compatibility factor, communicative abilities. \section{problem}

Introduction and the current state of the research

Management is a multidimensional concept that includes technical, economic, psychological, and social factors. It is the interdisciplinary field that has an important meaning for the society. To effectively conduct multifaceted managerial activity requires a systemic approach. Effective management is manifested in transformation of the system from the existing state to the desired state. In management there are always two components the subject, the one who provides managerial functions, and the object to whom the managerial actions are directed. The subject and the object of management form a unified management system. That is, management is the targeted influence of the subject on the object with the ongoing process of developing and implementing solutions aimed to the achieving of a final positive result.

Psychology has a lot to contribute to management in general, and more specifically to the management of projects. Projects are done in groups; they require team members to communicate, empathize, comprehend, influence and engage. Moreover, there is a crucial need to understand what motivates individuals to improve performance within teams, and to encourage the adoption of proposed change. Each person has a unique personality, some people are good in some things, while others are good in something else. Hence, the golden rule in dealing with people is not try to change people, but rather build on what they are and compensate for what they are not.
To give a person the wrong role is like to ask him to be what he is not. When he is pressed to be what he is not, he does not feel good and does not perform as effective. But when he is placed where he feels "in his shoes", everything changes - he feels good, his productivity increases and all the rest comes with it. Then people around him are amazed about the changes in him. But he has not changed, he became himself. Morris Viteles, who is considered as one of the fathers of industrial psychology and an enthusiast of taking the human element into the practice of management, wrote: "It is important that a man be kept out of a job for which he is not fitted. It is even more important that he be placed in a job where he can be efficient and happy" (Wallace, 1996). Such an approach should be a sort of guiding star for managers in their work with people.

The aim is to let people to imbued with an understanding of the need to use psychological methods in the process of management for elevating people's satisfaction at the workplace and enhancing performance.

\section{Tasks}

To underline that the society of owners and helpers has been developed into the society of organizations as a demand of the developing industries.

To follow how, in historical perspective, management as a scientific and applied discipline grew from the application of mechanistic approach to the use of psychological methods in managing people's activity. To emphasize on the emergence of managers, the new 
type of specialists in industries whose functions are to plan, organize, making decisions, developing people and oversee the production process.

\section{Research methods}

Analysis of the current state of the psychological aspect of management in American literature. subject.

Review of the author's own multiple writings on the

Application of the author's years of hands-on experience as a manager of construction projects in San Francisco, California, USA.

\section{Research results}

The history of the subject

Historically, until the time of industrial revolution of nineteenth century, the concept of management and managers did not exist. The society was the society of owners and their "helpers". In the twentieth century, our society became a society of organizations. The development of the society into the society of organizations led to a demand for people who were neither owners nor helpers. The new society needed people who practice professional management: planning, organizing, integrating and developing people etc. Thus, the emergence of management as a scientific and applied discipline was not accidental. It was an answer to the developing society. Management as a specific activity has been developed (Griffin, 1999). It identifies the concept of management as the "set of activities directed at an organization's resources - physical, informational, financial and human-with the aim of achieving organizational goals in efficient and effective manner". The efficient manner means using resources wisely and in a cost-effective way. The effective manner means making the right decisions and implementing them successfully.

The term management was first popularized by Frederick Winslow Taylor who is considered the earliest advocates of scientific management. In 1881 he proposed his scientific management theory as a way of making the conduct of work-related activities more efficient. He described his method in the book The Principals of Scientific Management (Taylor, 1911). The major postulate of the theory was an assumption that individual workers would be willing to work hard for monetary rewards. Taylor introduced wage incentives schemes so that workers could get paid more for the increased production. The book has inspired administrators to adopt productivity-enhancing and waste-reducing procedures and measures. Despite the fact that the wage is still considered the main motivating factor for increasing productivity, motivation by the only economic incentives works up to the certain point. People see more than just earnings in their work, they are filled with thoughts and ideas and want to see them implemented along with receiving monetary rewards. Taylor believed that managers are required to do all the thinking related to the planning and design of work, leaving workers with the task of implementation. He writes, "In our scheme, we do not ask the initiative of our men. We do not want any initiative. All we want of them is to obey the orders we give them, do what we say, and do it quick." (Taylor, 1903). In his endeavor to maximize manual efficiency Taylor abandoned the nuances and strengths of human nature and capability displaying psychological illiteracy. Indeed, a key criticism of Taylor's approach was that he treated people as attachments to the machines. By concentrating on efficiency, he discounted and ignored human factors, addressing tasks and their execution without considering the human and their impact.

One of the earliest critics of Taylor's work was Lillian Gilbreth, an engineer and industrial psychologist. She was the first one who instigated the psychological aspects of scientific management by exploring the psychological element within management in order to complement and augment the scientific management perspective. She described her vision in the book The Psychology of Management: The Function of the Mind in Determining, Teaching and Installing Methods of Least Waste (Gilbreth, 1914). Lillian Gilbreth incorporated concepts of human relations and worker individuality into management principles. It was a major early work in the field of industrial psychology. She expressed the view that scientific management should be built on the principle of recognition of the individual, stressing the importance of including the human element in management. Her contribution has been essential in positioning psychology in the context of management and emphasizing its role and value. Although her work has become less popular nowadays, Lillian Gilbreth is recognized as the 'first lady of management' (Hindle, 2008). By concentrating on efficiency Taylor had managed to discount and ignore human factors and needs. Gilbreth made important advances by progressing the search for efficiency to bring the human subjects and participants into consideration.

Within the following decades human relations movement was gradually gaining strength, and mostly so after the World War II. The courses on the subject were included into universities' programs in the United States and in some European countries. In the 1970s' the movement also found its reflection in the former Soviet Union. In particular, Dr. Gregory Bedny ${ }^{1}$ and the author of this article gave related lectures to managers of industrial organizations in Odessa, and at the Odessa Construction Engineering University.

Fast forward to our times. In our recently published book on the subject of psychological aspect of management, The Psychology of Effective Management: Strategy of Relationship Building (Voskoboynikov, 2017), we tried to advance the agenda put forward by Lillian Gilbreth in 1914. Our emphasis was on encouraging a deeper consideration for the role of the human element in managing. Darren Dalcher, Director of the National Centre for Project Management in the UK, commenting on the book, writes, "Throughout his work, Voskoboynikov distils the practical implications of good management practice that are centered on human performance and achievement. He acknowledges the dramatic changes in human work in the last century, which increas-

\footnotetext{
${ }^{1}$ Dr. Gregory Bedny was a graduate of the University of South Ukraine, and in later years worked there as a Professor of Psychology before immigrating to the United States in 1989.
} 
ingly require greater reliance on human intelligence, knowledge and insights and the need to integrate human capabilities and improve performance. Voskoboynikov, therefore, is able to progress the discussion from one concerned with mechanistic efficiency towards one that addresses the challenges of modern life by embracing and acknowledging the role of effectiveness" (2018).

\section{The concept of manager}

The concept of manager has to do with all people whose functions are to manage other people's activity. Business owners and plant foremen, supervisors and heads of departments, commanders of military units and coaches of athletic teams, and many others fall into the category of managers. Regardless of the type of organization and the field of activity, management functions are essentially the same. In fact, management functions are considered to be universal. Managers plan and organize, coordinate and control, make decisions, motivate and reward. All these functions can be combined into four categories of resources: physical, informational, financial and human. The content of the first three categories is vary significantly depending on the specifics of the organization or business. Whereas for maintaining the fourth category of resources, the human resources, there is a lot of similarity regardless of the specifics of organizations.

Most of attention in any organization is directed toward achieving financial goals, that is, toward profitability. That is vital for the organization and well understood. However, particularly for this reason, people's interests are not often on the priority list in organization's affairs. If that is the case, sooner or later such an approach will backfire and prevent the organization from functioning successfully in the long run. Regardless of how "intelligent" the technology is and how the society progresses, humans always play a leading role in the functions of organizations. There are already fully automated plants where robots perform all technical operations. However, all of it takes place under people's control. Technicians came periodically, they turn the robots off and check whether there is a need for any necessary adjustments, and so on. Even if robots themselves signal what adjustments or repairs are needed, people are still the ones who monitor the repairs or adjustments. In pilots' activity, for example, in a case of a system failure the manual controls need to be used in takeoff and landing. In other words, machines and materials cannot "work" without people's involvement.

Many factors influence on the psychological environment in the workplace, but the strongest one comes from the manager. The way managers relate to subordinates effects the group morale and psychological atmosphere in the workplace. If the manager does not project a positive image, it automatically transmits into the relations between the team members. The working environment becomes stressful, people less incline to cooperate with each other, they feel uncomfortable and morally vulnerable. This factor affects the whole nature of business communication. To know people's individual characteristics, their ability to work in a group environment, as well as their values, goals, and desires is just as necessary for managers as possessing the technical knowledge in the chosen field of activity. Hence, directing all possible efforts toward creating a positive psychological environment in the workplace is of a significant importance. To create such an environment without basic knowledge of psychology does not seem possible. Therefore, the knowledge of people's psychology is crucially important and ought to be a necessary element in the arsenal of any manager for the purpose of achieving maximum performance on the background of people's satisfaction in the workplace.

\section{Psychological factors applied to management \\ Individual-focused approach}

To take an individual-focused approach in working with people is necessary for creating a cohesive team. From the social psychology perspective, the team is a small social group of persons who unite and cooperate for achieving the common goal. For the successful functioning of the team two factors are of the most importance: team members must possess the needed technical skills and experience in the field and they must complement each other. The first factor is usually well taken into account, but the second one is not always paid much attention to. Each person is different in his or her own unique way. Some people are quick and can easily adapt to the changing environment, others are slow and are not as dynamic. Some individuals can sustain tough impacts while others can't, but the latter are able to navigate in slightly noticeable changes of the surroundings, which enable them to react more keenly. Some feel comfortable in performing monotonous work while others are "falling asleep" in doing same. Some people are happy to work in a group environment, others prefer to work on individual assignments. As a result, managers will best benefit from what people are capable of and they will experience satisfaction by their performance. Respecting people's individuality and using it the best possible way will eventually benefit the team and the entire organization. Hence, the golden rule in dealing with people is not to try to change people, but rather to build on what they are and compensate for what they are not.

\section{Individual personality features}

Individual characteristics of a person is a product of his or her heredity, physical being and the acquired experience of humankind. Temperament is an important characteristic of personality which manifests itself in activity. Temperament characterizes people's behavior from the position of force with which they respond to the same stimuli. It characterizes people only by the dynamic of their reaction on the impact and does not predetermine their mental ability or social significance. There are four known conditional temperament types. We will restrict ourselves to a very brief description of the types. People of sanguine temperament have a strong nervous system. They steady in their feelings and actions, they are sociable, talkative, easily converges with new people. Choleric type is individuals with a strong nervous system, quicktempered, straight-forward and aggressive. They are characterized by stable aspirations and persistence in achieving their goals and are capable in overcoming great diffi- 
culties. People of choleric type are characterized by prevailing of excitation over inhibition. They are the ones who have "bad brakes" so-to-say. To put such individuals on the front line of communication with customers, where "customers are always right", is hardly a good idea. Phlegmatic type is individuals with a strong nervous system. They are balanced, diligent, patient, and peaceful and tend to be self-content and kind, relaxed and rational. People of melancholic type are individuals with a week, easily vulnerable nervous system, capable of sustaining a short-term stress. Melancholic type persons are usually perfectionists, can sustain monotonous work, they possess an ability to pay close attention to details which is quite important in a number of professions.

The descried four general types quite rare exist in a "pure" form. Indeed, many of us exhibit some mixture of temperament characteristics. This is how it can be explained. In any classification, the type is characterized by the severity and the ratio of its constituent properties or other characteristics. Theoretically, the degree of severity of the properties may vary indefinitely thereby creating endless number of possible types. However, in reality, there is no need for such theorization and the typeapproach can be used for practical purposes. Singling out the most prominent feature of temperament attributes a person to one or another type. While one temperament type better relates to some kinds of activity, another type is good for some other kinds of activity. To take subordinates' temperament type and other personality features into account in the process of management is helpful for the purpose of achieving the team's objectives.

\section{Individual style of performance}

Any kind of human activity present more than one objective requirement to people in order to perform. Some personality features better relate to the requirements of activity, others - not as much. It enables people to compensate their weak qualities by the more outstanding ones. It based on the principal of self-regulation. The process of self-regulation manifests itself in a formation of desired goals and in developing a program of actions which correspondence with these goals, with conditions for achieving the goals, and with peoples' individual abilities. That is, people attempt to diminish the impact of their weaker features of personality in a given task situation utilizing their strong features for a more efficient performance.

There are two ways of ensuring the effectiveness of human performance. One is by professional selection, the so-called "screening out" individuals with specific attributes. The other one is through individual training methods directed towards the formation of individual strategies of activity based on personality features of the individual in the process of adaptation to the objective requirements of activity. The central notion in this area of study is the individual style of activity that connects features of personality with mechanisms of self-regulation. According to the concept of individual style of activity people can efficiently adapt to the objective requirements of activity by utilizing the non-normatively prescribed methods of performance, but rather by their own individual style of activity. Other words, people through trials, errors and feedback corrections create strategies of performance suitable to their individuality. For example, people with an inert nervous system develop a predisposition to organize and plan their work in advance and attempt to utilize a stereotyped method of performance.

The concept of individual style of activity was first introduced by the Soviet psychologist Merlin (1964). In subsequent years, some other authors also studied the effect of individual personality features on performance (Bedny and Voskoboynikov, 1975). The outcome of the studies was establishment of the fact that different individuals can perform with equal efficiency using their strategies of performance that are more suitable to their personality features. That is, people attempt to compensate for individual weaknesses with their personal strength in a given task situation. By implementing the individual style of activity on performance, they diminish the impact of their weaker features of personality. Individual style of activity should be considered strategies of performance deriving from the mechanism of self-regulation, which depend on personality features (Bedny and Seglin, 1999; Voskoboynikov, 2014). The process of self-regulation manifests itself in a formation of the desired goals, in developing of a program of actions that correspondents with these goals, with conditions for achieving the goals, and with a person's individual abilities. In other words, people through trials, errors, and feedback corrections create strategies of performance suitable to their individuality. For example, people with an inert nervous system develop predisposition to organize and plan their work, and attempt to utilize stereotyped method of performance. Based on the individual style the subject can adapt to the situation more efficiently. Understanding of individual features of personality allows managers to assign the more adequate tasks for individual subordinates, and develop individual strategies of social interaction with subordinates. It suggests that managers should rely on people's strong qualities instead of insisting on fixing the weaker ones. As a result, managers will best benefit from what people are capable of and they will experience satisfaction by their performance.

\section{Communicative abilities}

Not all people easily get into contact with others. People's communicative abilities are different, and as a consequence, their preferences of communication with others are different too. Some people feel comfortable working shoulder to shoulder in groups, others prefer to work on individual assignments, some feel in "their shoes" when they lead others, while others feel comfortable being followers. The ability to communicate with people has its effect on both the team cohesiveness and on individual and group performance. A study conducted by psychologists of Leningrad University (now St.- Petersburg University, Russia) in 1960s revealed four distinct types of communicative personality traits, which is manifested in ability for interpersonal communication: leading, followers, closed, cooperating.

Leading type refers to people with a strong focus on power in the group. Such individuals can work more pro- 
ductively subject to the submission of other group members. Follower is the type with a pronounced orientation to the voluntary submission. Persons of this type can successfully participate in the solution of the group task only on condition of subordinating to a more confident, independent and competent member of the group. As a rule, such people are good performers. The relationship between the follower and the group is built on the basis of exposure to group influence. They are satisfied with such a position since they do not need to make decisions, which is not always an easy task. Closed type is the type with a pronounced individualistic orientation. They prefer working on individual assignments, they do not strive for leadership and cooperation. In this regard, it is advisable to use individuals of the leading type for carrying out organizational activities. People of the follower type, respectively, should be used performing tasks given them from "the above". Closed type can successfully and efficiently work in performing independent tasks with a minimum degree of interaction with other group members. Cooperating type is good for working together with other members of the production group on an equal footing, without clearly singling out the leading position of any of them. They are striving to work together with others and follow them in case of reasonable decisions for the task solutions. As a rule, persons of this type are good partners in business.

To take into account the differences in people's communicative characteristics allows to avoid a possible psychological mistake when completing the group for performance of the group tasks. In a group with two members of the leading type of communicative behavior and in a group that consists of followers and closed ones, the performance may be negatively affected. In the first case it maylead to conflicts, in the secondto uncertainty and confusion.

The Effect of Group Activity on Individual Performance

The increasing complexity of social structures and technological progress increases the share of collective knowledge-intensive sectors of industry which highlights the problem of increasing the effectiveness of individuals' joint activities. In the study of the group activities an object of research becomes a group of people linked by a common purpose. Their activity is connected by the means of carrying out a common task. The concept of a group activity indicates multifaceted phenomenon, which must be differentiated.

It has long been observed that people behave differently in group settings as compared to the behavior in private. This is because the group is not the arithmetic sum of separate individuals, and the result of the group performance is not always a positive sum of the results of individual performances by its members. Individual in a group appears in a new capacity - as a component of the system "individual - other individuals". Groups have properties of their own; they are different from the properties of the individuals who form the group. Just as a combination of copper and tin results an alloy, which hardness is neither of each of them, people in the group act and behave differently. Representatives of various professions and other kinds of activity such as polar explorers, mountain climbers, commanders of aircrafts and ships' crews experience in real life that not all people are equally fit for complex teamwork. For the effective execution of tasks in group environment not only technical skills of the group members are needed to be considered, but also the degree of compatibility between them as well. Depending on the degree of compatibility the result of the group performance may either be equal to the sum of the results of individual performances, or greater or lower than that sum. Examples of the incompatibility can be observed in a working crew, where there is a significant difference in workers' skills, or an athletic team formed by athletes of different skill levels. This kind of incompatibility is called physiological. In these examples such physical parameters as height, physical strength, motor skills etc. are described. To note such differences in people is not that difficult and it's unlikely that anyone will instruct people with such differences to perform a task where these differences present a hindrance.

People always experience certain flow of feelings toward others. These feelings are based on the differences of psychological nature, such as temperament, character, social orientation, habits, amateur interests and so on. They may be positive or negative, or neutral, they can be mutual or non-mutual and therefore conflicting. The incompatibility by the described differences is called psychological. These differences are not always obvious and apparent, but precisely the differences of this kind have a decisive impact on compatibility and, in turn, on the group and individual performance. Psychological incompatibility has its negative influence not only on the group and individual performance, but on human health as well. Unfriendly uptight relationships between group members call up negative emotions. In mass professions, where there are no expressed extreme conditions, people can perform productively under the influence of negative emotions for a fairly long time. It's important to understand that all of this flows at the expense of the unnecessary stress. Working activity on the background of negative emotions for a long period of time may cause pathological developments in the central nervous system, which could lead to various diseases of a neurotic order. People become irritable, experience headaches, insomnia, blood pressure disorders, dysfunction of gastrointestinal tract, and other deviations in health condition. Typical medical approach for the treatment of such conditions does not always give positive results. There are statistical data in different countries on the loss of a large number of manhours as a result of the nervous breakdown due to psychological incompatibility.

Management styles

In the world of management today we can observe many different management styles and their variations. Some authors identify five styles, others - six, some even describe thirteen. Regardless of the number of styles and terminology, the main thing is to follow how managers make decisions and how they relate to their people. That in turn influences on the group dynamic and on the 
working atmosphere. Some managers demand from subordinates to obey their instructions with no explanation and discussions, whereas others encourage subordinates' initiative and active involvement in the problem solving and decision making. That is, basically we are talking about two opposite approaches (with some variations and the degree of their manifestation) in relation to subordinates.

Representatives of the former are basically characterized by the desire for excessive centralization of power, exaggeration of the role of administrative methods, the sole solution of the most questions without discussing them with subordinates. Representatives of the latter are characterized by allowing group members into coordinated activities and by maximizing their involvement into joint definition of group goals. These managers do not seek concentration of the power and contacts, but rather vice versa. They try to delegate responsibility to, the socalled, informal leaders of the group, to the ones who possess the informal authority by their knowledge, ability to communicate with other group members etc. However, we must note, that the most important thing about these two management styles is that both styles are good to use depending on the specific of the team activity, on the situation and other factors. It can be illustrated by the following example. If the subordinate is competent and well aware of his/her responsibilities the use of the authoritative approach would not be justified, this subordinate mostly in a need of support and positive motivation. In the opposite case, if the subordinate does not have the sufficient knowledge and experience, the manager's clear directive instructions and oversight will intensify his/her activities. If the manager limits the action in relation to this particular subordinate only by friendly support will do no good.

There is another management style which differs from either style described above. It's called liberal or passive by different authors, or chaotic by others. Managers practicing this style are usually people who are not very knowledgeable in the field and often take the position for advancing the self-serving tactical goal to "jump" to a different (often higher) position in the nearest future. Or, they are people who conscientious and responsible by nature, but with the features of inertness. Management activity of such managers is reduced to transferring the directives from the "above" down and to function as observers and collectors of information. They give to subordinates maximum independence in their work. This management style cannot be effective in the production environment, in the power structures, in collectives where the activity takes place in extreme conditions etc. However, this style is quite acceptable in activity where control and guidance are not necessary. For example, activity of the teaching staff in the universities' depart-

\section{References}

1. Bedny, G. Z. and Karwowski, W. (2007). A Systemic-Structural Theory of Activity. Application to Human Performance and Work Design. Boca Raton, FL: Taylor $\&$ Francis Group. ments, in the scientific institutions, and everywhere else where creativity is the essence of the work.

\section{Discussion}

In this work, we described that the emergence of management as a scientific and applied discipline was not accidental. The development of the society into the society of organizations led to a demand for people who were neither owners nor helpers. We emphasized, that ensuring the effectives of managerial activity requires a new way of thinking which is characterized by the systemic flexible, responsive, and non-standard approach to the decision making.

We further emphasized that according to the systemic-structural activity theory, as a scientific basis for self-regulation, human activity is considered to be a goaldirected self-regulative system. In particular, individual style of activity allows the subject to adapt to the situation more efficiently by connecting features of personality with mechanisms of self-regulation and strategies of performance.

We underlined that implementing psychological factors into the process of management for creating an optimum psychological atmosphere in the workplace for achieving maximum performance is of a significant importance. Such factors as consideration for subordinates' personality features, their communicative abilities, as well as their values and expectations, their goals and desires, is essential for the effective implementation of managerial activity. The effect of a group environment on individuals' behavior and performance, and the phenomenon of psychological compatibility were also discussed in this work.

\section{Conclusion}

Activity theory distinguishes two types of activity: "object-oriented" and "subject-oriented". The former is referred to a subject using tools on material objects with the goal to complete the task and evaluate the results. The latter is referred to social interaction between people, which is the most important element in management. On the level of ordinary consciousness, each of us feels as psychologically perfectly fit and qualified on the basis of life experience to act as engineers of human souls. However, to manage people effectively in our modern times, require some basic knowledge of psychology as a valued addition to the technical expertise in a chosen profession.

Managing people at work is not a part of the management process but rather a management as a whole. Regardless of the field of activity, managers work with people. A bank manager does not manage computers, safes, and accounts; a construction manager does not manage machines and equipment; basketball coach does not manage game tactics and techniques; a ship captain does not work the steering wheel but nevertheless gets to the desired destination by managing the ship's crew. Managers manage people!

2. Bedny, G. Z. and Seglin, M. (1999). Individual style of activity and adaptation to standard performance requirements. Volume 12, No.1, p.p. 59-78. Human Performance. Mahwah, NJ: Erlbaum. 
3. Bedny, G. Z. and Voskoboynikov, F. A. (1975). Problem of how a person adapts to the objective requirements of activity. In Aseev, V. G. (Ed.). Psychological Problems of Personality, Volume 2, 18-30, Irkutsk, Russia: Irkutsk University Press.

4. Dalcher, D. (2018). What has Taylor ever done for us. In Darren Dalcher (Ed.) Managing Projects in a World of People, Strategy and Change, p.p. 2938. Milton Park, Abingdon, (UK): Routledge.

5. Gilbreth, L. M. (1914). The psychology of management: The function of the mind in determining, teaching and installing methods of least waste. New York: Sturgis and Walton.

6. Griffin, R. Management. (1999). Mason, Ohio: South Western Cengage Learning.

7. Hindle, T. (2008). Guide to management ideas and gurus. London: The Economist.

8. Merlin, W. S. (1964). Outlines of Theory of Temperament. Perm: Perm Pedagogical University. Taylor, F. (19110. The principal of scientific management. New York: Harper \& Brothers.
9. Morgan, G. (1997). Images of Organization. 2nd ed. Thousand Oaks, Calif.: Sage.

10. Taylor, F. (1910). The Principal of Scientific Management. New York: Harper and Brothers.

11. Taylor, F. W. (1903). "Shop management; a paper read before the American society of mechanical engineers" in: Transactions of the American Society of Mechanical Engineers 24: 1337-1480.

12. Voskoboynikov, F. (2017). The Psychology of Effective Management: Strategies for Relationship Building. New York: Routledge.

13. Voskoboynikov, F. (2014). The Influence of Personality Features on Performance in Work, Study and Athletic Activity. In Tadeusz Marek et al (Ed.) Human Factor of a Global Society: A System of Systems Perspective. pp: 187-192. Boca Raton, Fl: Taylor \& Francis Group.

14. Wallace, A. (December 11, 1960). Morris Viteles, Industrial Psychologist. Philadelphia Enquirer.

\section{Почесний професор з психологіі (Балтійська Педагогічна Академія, вул. Декабристів, 25, Санкт-Петербург, Росія),} бакалавр з різілогї магістр в галузі промислово-організаиійної психології, 129, проспект Идора, Сан-Францичкко, Каліфорнія, США

СИСТЕМНИЙ ПІДХІД ДО ВПРОВАДЖЕННЯ ПСИХОЛОГІЧНИХ ФАКТОРІВ В УПРАВЛІННІ

У цій роботі розглядаються деякі аспекти управління в умовах викладання науково-прикладної діяльності. Забезпечення ефективності управління вимагає нового способу мислення, що характеризується системним, гнучким та нестандартним підходом до прийняття рішень. Відповідно до теорії системно-структурної діяльності, людина розглядається як цілеспрямована саморегулятивна система. Основна увага в нашій роботі зосереджена на тому, що є важливим для управлінської діяльності з психологічної точки зору. Особлива увага приділена відносинам керівників до підлеглих та тому, як цей фактор впливає на моральну та психологічну атмосферу групи на робочому місці. Володіння лише технічними знаннями у вибраній галузі діяльності не обов'язково робить людину успішним менеджером. Доведено, що задля досягнення бажаних цілей та підтримки ступеня задоволення людей на робочому місці, необхідно враховувати специфіку їі саморегуляції. У роботі представлено важливі фактори психологічного характеру, які слід застосовувати до практики управління, а саме: врахування особливостей особистості підлеглих, їх індивідуального стилю виконання та їхніх комунікативних здібностей, а також цілей та завдань. Розглянуто вплив групового середовища на індивідуальну діяльність та психологічну сумісність; історію мотивації в промисловості та появ нового напрямку в управлінській діяльності в суспільстві, що розвивається. Встановлено, що наука управління вперше виникла у формі застосування механістичного підходу людей у різних галузях промисловості.

Ключові слова: менеджмент, стилі управління, теорія діяльності, системно-структурна теорія діяльності, психологічні фактори в управлінні, особливості особистості, індивідуальний стиль діяльності, фактор сумісності, комунікативні здібності. 